introducing there his new 'secondary' method of structural X-ray analysis, and, as research director in physical chemistry, practical classes in photochemistry and colloids. He became assistant professor in 1934.

However, the Nazi era altered Böhm's scientific life. Profs. v. Hevesy and Böhm had to leave Germany. The latter, who always kept his Czechoslovak nationality, accepted the invitation of the Czechoslovak government to the chair of physical chemistry at the German University in Prague. During the German occupation of Prague, Böhm was again subjected to political pressuro; but he never joined the Nazi party, and continued to help his numerous Czech friends in their scientific work in a fearless manner.

Böhm's own research work in the war years concerned again $\mathrm{X}$-ray investigations and photography; but it remains mostly unpublished, as his pupils left Prague in the critical year 1945. When conditions settled down again, Böhm was employed as a research chemist in the national enterprise Rybitvi near Prague, and remained there in spite of several offers of a post as a university teacher. The many sufferings he had sustained had deprived him of self-confidence. At last he consented to work in the physico-chemical laboratory of the Czechoslovak Academy of Science and was one of the first of the nominated corresponding members of that institution.

Prof. Böhm possessed not only a great capacity for experimental work, but also a unique strength of character. His philosophical attitude and faith in social justice guided him safely through national and political struggles. His great modesty, self-denial and willingness to help others led to over-work, which destroyed the hopes of his friends just when he had returned to academic research.

$$
\text { J. HeYROVSKÝ }
$$

\section{Prof. Otto Pratje}

Prof. Otto Pratje, who was both head of the marine geological section of the German Hydrographic Institute and lecturer in geology at the University of Hamburg, died on December 11, at the age of sixty-two.

Although originally committed to a commercial career, Pratje studied geology concurrently for several years in Britain and Swedon. After the First World War, he decided that his profession was not to his taste, and took his doctor's degree at Freiburg in 1921 under Deecke. During the ensuing period he worked as an assistant at the University of Freiburg on the marine sediments of the Continent of Europe.

The course of his life's work was, however, decided by his move to Königsberg, where he acted as a university assistant and lecturer during 1923-27. His chief study was the geology of the sea-bed, and it was to this that he owed his participation in the Meteor Atlantic expedition during 1925-26. In 1937 he was appointed to establish and direct the marine geological section of the Deutsche Seewarte at Hamburg. After the Second World War he joined its successor, the German Hydrographic Institute, and also became a member of the lecturing staff of the University of Hamburg.

The abundance of Prof. Pratje's publications bears witness to his diligence and fertile mind, and will bo a lasting monument to him. While his earlier papers were devoted to the geological and palæontological problems of the Continent, in particular those of the
Jurassic formations of south-west Germany, marine geology came more and more into the foreground during the Königsberg period. At first he wrote several papers on Heligoland, including the wellknown geological guide, but then turned completely to the sea-bed. He also made a systematic collection of bottom samples during many research voyages. In addition to a number of papers on the formation of sediments in the North Sea and the Baltic, we owe to him what are believed to be the most detailed geological charts of these seas yet compiled. Parallel with this work, Pratje carried out the laborious evaluation of the bottom samples collected during tho Meteor expedition, of which two parts have appeared in print. Unfortunately, his official duties, combined with war-time and post-war conditions, prevented the completion of this work. Finally, in an extensive paper in the "Handbuch der Naturwissenschaften", he described the techniques and methods of collecting and evaluating samples from the ocean bottom, supplementing it, in the "Jahrbuch der Geographischen Gesellschaft", with references to his most recent experience.

Prof. Pratje laboured much and achieved much, though some of his work was incomplete when he died. What remains is the memory of a kindiy man who was always ready to collaborate, in whose presence no harsh word was ever heard, and who knew how to suffer hard blows with a quiet mind.

\section{Prof. Francesco Vercelli}

WE regret to report that the distinguished Italian geophysicist, Prof. F. Vercelli, director of the Geophysical Observatory and of the Thalassographical Institute of 'Trieste, died, at the age of sixty-nine, on November 24.

Prof. Vercelli contributed to rescarch in several branches of geophysics. In oceanography he investigated the transmission of solar radiation through sea and lake water and the effects of wind and pressure variations on the tides, and led oceanographic expeditions in Italian naval vessels to various parts of the Mediterranean and Red Sea. He devised a method of harmonic analysis and applied it to the prediction of pressure changes. He sought for the sunspot cycle in tree-ring records. His earliest geophysical work was concerned with temperature in tunnels in connexion with the construction of the Simplon tunnel; later, he founded a seismological station at Trieste and took part in seismic and electromagnetic prospecting for oil in the Po valley.

$\mathrm{He}$ was appointed director of the Geophysical Institute of Trieste in 1920. When the Institute was divided in 1949, ho became director of both the Geophysical Observatory and the Thalassographical Institute. His last years were devoted to preparing a second edition of his book on meteorology, "L'Aria", and to writing a large work on oceanography, "II Mare".

WE regret to announce the following deaths :

Prof. G. D. Hale Carpenter, M.B.E., Hope professor of zoology in the University of Oxford during 193348 , on January 30 , aged seventy.

Prof. J. H. Orton, F.R.S., emeritus professor of zoology, University of Liverpool, and formerly director of the Marine Biological Station, Port Erin. on February 2, aged sixty-eight. 